\title{
Analisa Pengaruh Variasi Sudut Sambungan Belokan Terhadap Head Losses Aliran Pipa
}

\author{
Zainudin*, I Made Adi Sayoga*, I Made Nuarsa* \\ Jurusan Teknik Mesin, Fakultas Teknik, Universitas Mataram \\ Jalan Majapahit No.62 Mataram
}

\begin{abstract}
On the water distribution, the connection of pipe bends is typically obtained either in industry or in housing. On the water distribution, it is often gained the lost of energy or head losses. The amount of head losses occurring in the connection of branch pipe is influenced by several factors, such as: diameter, flow, viscosity, and the angle at the bend pipe connections.

This study aimed to determine the effect of variation of the connection point of the bend pipe to the head losses and pressure drop. To do it, the researcher uses an experimental method as a tool by varying the bend angle is $30^{\circ}, 45^{\circ}, 60^{\circ}$, and $90^{\circ}$.

The result shows that head losses and the small pressure drop occur in the bend angle $30^{\circ}$ is 73, $23 \mathrm{~mm}$ and $907.606 \mathrm{~N} / \mathrm{m} 2$. While the head losses and pressure drop is the greatest at an angle of $90^{\circ}$, is $74,80 \mathrm{~mm}$ and $1278,899 \mathrm{~N} / \mathrm{m} 2$.
\end{abstract}

Keywords: the connection of pipe bends, head losses, pressure drop.

\section{Pendahuluan}

\subsection{Latar Belakang}

Setiap hari kita semua selalu berhubungan dengan fluida hampir tanpa sadar. Banyak gejala alam yang indah dan menakjubkan, seperti bukit-bukit dan ngaraingarai yang dalam, terjadi akibat gaya-gaya yang ditimbulkan oleh aliran fluida. Semua fluida mempunyai atau menunjukkan sifatsifat atau karateristik yang penting dalam dunia rekayasa.

Penerapan pinsip-prinsip mekanika fluida dapat dijumpai pada bidang industri, transportasi maupun bidang keteknikan lainnya. Namun dalam penggunaannya selalu terjadi kerugian energi. Dengan mengetahui kerugian energi pada suatu sistem yang memanfaatkan fluida mengalir sebagai media, akan menentukan tingkat efisiensi penggunaan energi.

Bentuk-bentuk kerugian energi pada aliran fluida antara lain dijumpai pada aliran dalam pipa. Kerugian-kerugian tersebut diakibatkan oleh adanya gesekan dengan dinding, perubahan luas penampang, sambungan, katup-katup, belokan pipa, percabangan pipa dan kerugian-kerugian khusus lainnya. Dengan mengetahui kehilangan atau kerugian energi dalam suatu sistem atau instalasi perpipaan yang memanfaatkan fluida mengalir sebagai media, efisiensi penggunaan energi dapat ditingkatkan sehingga diperoleh keuntungan yang maksimal. Salah satu bagian dari instalasi perpipaan yang dapat menyebabkan kerugian-kerugian adalah gesekan pada dinding pipa dan sambungan belokan pipa.
Kualitas pipa dan fitting kecuali di tentukan berdasarkan kualitas fisik berupa tampilan warna, dimensi, sistim koneksi (ulir atau flange) dan lain sebagainya ditentukan pula oleh head losses apabila dialiri fluida. Semakin besar head losses semakin berkurang kualitas pipa dan fitting tersebut. Kualitas fisik dapat mudah dikenali oleh konsumen, namun head losses harus dilakukan penelitian laboratoris (Edi Suhariono: 2008).

Pada pendistribusian air sambungan belokan pipa sangat banyak ditemukan baik di industri ataupun di perumahan. Dilihat dari jenis belokannya terdapat dua jenis belokan dalam sambungan pipa, yaitu sambungan belokan patah dan sambungan belokan yang berjari-jari. Dari kedua jenis belokan tersebut yang sering dan paling banyak ditemukan adalah sambungan belokan berjari-jari.

Besarnya head losses pada sambungan belokan pipa tersebut dipengaruhi oleh beberapa factor, seperti: diameter, debit, viskositas, dan sudut pada sambungan belokan pipa tersebut.

\subsection{Tujuan Penelitian}

Adpun tujuan yang ingin dicapai dalam penelitian ini adalah:

1. Mengetahui besarnya head losses terhadap perubahan sudut sambungan belokan pipa.

2. Mengetahui perbedaan tekanan (pressure drop) dalam pipa pada tiap perubahan sudut sambungan belokan pipa. 


\section{Teori}

\subsection{Definisi Tentang Fluida}

Menurut Raswari (1986), fluida merupakan suatu zat/bahan yang dalam keadaan setimbang tak dapat menahan gaya atau tegangan geser (shear force). Dapat pula didefinisikan sebagai zat yang dapat mengalir bila ada perbedaan tekanan dan atau tinggi. Suatu sifat dasar fluida nyata, yaitu tahanan terhadap aliran yang diukur sebagai tegangan geser yang terjadi pada bidang geser yang dikenai tegangan tersebut adalah viskositas atau kekentalan/kerapatan zat fluida tersebut.

Fluida dapat didefinisikan sebagai suatu zat mampu alir dan dapat menyesuaikan bentuk dengan bentuk wadah yang ditempatinya, serta apabila diberikan tegangan geser, betapapun kecilnya akan menyebabkan fluida tersebut bergerak dan berubah bentuk secara terus-menerus selama tegangan tersebut bekerja (White, 1986).

Dengan pengertian diatas maka fluida dapat dibedakan atas zat cair dan gas. Dimana kedua zat ini pun berbeda secara teknis akibat gaya kohesif. Zat cair cenderung mempertahankan volumenya dan akan membutuhkan permukaan bebas dalam medan gravitasi. Aliran muka bebas sangat dipenuhi efek gravitasi sedangkan zat gas akan memuai dengan bebas sampai tertahan oleh dinding yang membatasinya. Gas tersebut akan membentuk atmosfir yang pada hakekatnya akan bersifat hidrostatik.

\subsection{Aliran Laminar dan Turbulen}

Beberapa tahun yang lalu, Osborne Reynolds telah melakukan beberapa percobaan untuk menentukan kriteria aliran laminar dan turbulen. Reynolds menemukan bahwa aliran selalu menjadi laminar, jika kecepatan alirannya diturunkan sedemikian rupa sehingga bilangan Reynolds lebih kecil dari 2300 ( $R e<2300)$. Begitupula dikatakan alirannya turbulen, pada saat bilangan Reynolds lebih besar dari 4000 ( $\mathrm{Re}>$ 4000). Dan jika bilangan Reynolds berada diantara 2300 dan 4000 (2300 < Re <4000) maka aliran tersebut adalah aliran yang berada pada daerah transisi.

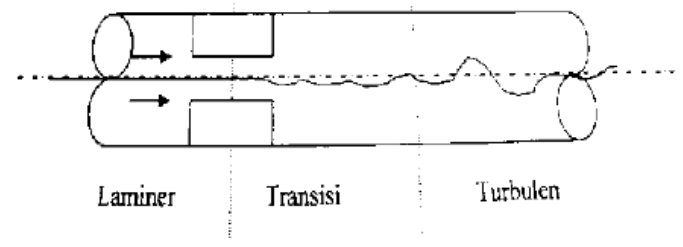

Gambar 1. Skema aliran dalam pipa Sumber : Streeter,(1988)
Untuk menganalisis kedua jenis aliran ini diberikan parameter tak berdimensi yang dikenal dengan nama bilangan Reynolds (White. 1986) sebagai berikut :

$$
\operatorname{Re}=\frac{\mathrm{vD}}{\mathrm{u}}
$$

Dengan: $\mathrm{Re}=$ bilangan Reynolds

$\mathrm{v}=$ kecepatan fluida $(\mathrm{m} / \mathrm{s})$

$\mathrm{D}=$ diameter pipa $(\mathrm{m})$

$\mathrm{U}=$ viskositas kinematika fluida $\left(\mathrm{m}^{2} / \mathrm{s}\right)$

\subsection{Persamaan Bernauli}

Hukum Bernoulli menjelaskan tentang konsep dasar aliran fluida (zat cair dan gas) bahwa peningkatan kecepatan pada suatu aliran zat cair atau gas, akan mengakibatkan penurunan tekanan pada zat cair atau gas tersebut. Artinya, akan terdapat penurunan energi potensial pada aliran fluida tersebut.

Konsep dasar ini berlaku pada fluida aliran termampatkan (compressible flow), juga pada fluida dengan aliran tak-termampatkan (incompressible-flow). Hukum Bernoulli sebetulnya dapat dikatakan sebagai bentuk khusus dari konsep dalam mekanika fluida secara umum, yang dikenal dalam persamaan Bernoulli. Secara matematis persamaan bernauli adalah sebagai berikut.

$$
\frac{\mathrm{p}_{1}}{\mathrm{~V}_{1}}+\frac{\mathrm{v}_{1}^{2}}{2 \mathrm{~g}}+\mathrm{z}_{1}=\frac{\mathrm{p}_{2}}{\mathrm{~V}_{2}}+\frac{\mathrm{v}_{2}^{2}}{2 \mathrm{~g}}+\mathrm{z}_{2}+\mathrm{H}
$$

Dimana :

$\mathrm{P}_{1.2}=$ tekanan di penampang 1 dan $2\left(\mathrm{~N} / \mathrm{m}^{2}\right)$

$\mathrm{v}_{1.2}=$ kecepatan di penampang 1 dan $2\left(\mathrm{~m} / \mathrm{s}^{2}\right)$

$\mathrm{z}_{1.2}=$ tinggi pada permukaan 1 dan $2(\mathrm{~m})$

$\mathrm{V}_{1.2}=$ berat jenis 1 dan $2\left(\mathrm{~N} / \mathrm{m}^{3}\right)$

$\mathrm{g}=$ gravitasi bumi $\left(9,82 \mathrm{~m} / \mathrm{s}^{2}\right)$

\subsection{Persamaan Kontinuitas}

Persamaan kontinuitas menyatakan hubungan antara kecepatan fluida yang masuk pada suatu pipa terhadap kecepatan fluida yang keluar. Hubungan tersebut dinyatakan dengan:

$$
\mathrm{Q}=\mathrm{A}_{1} \mathrm{v}_{1}=\mathrm{A}_{2} \mathrm{v}_{2}
$$

Dimana:

$A_{1}=$ Luas penampang pipa $1\left(\mathrm{~m}^{2}\right)$

$\mathrm{A}_{2}=$ Luas penampang pipa $2\left(\mathrm{~m}^{2}\right)$

$\mathrm{v}_{1}=$ Kecepatan fluida pada pipa $1(\mathrm{~m} / \mathrm{s})$

$\mathrm{v}_{2}=$ Kecepatan fluida pada pipa $2(\mathrm{~m} / \mathrm{s})$

Debit adalah besaran yang menyatakan volume fluida yang mengalir tiap satuan waktu:

$$
\mathrm{Q}=\frac{\mathrm{V}}{\mathrm{t}}
$$

Dimana:

$\mathrm{Q}=\operatorname{debit}\left(\mathrm{m}^{3} / \mathrm{s}\right)$ 
$\mathrm{V}=\operatorname{volume}\left(\mathrm{m}^{3}\right)$

$\mathrm{t}=$ waktu $(\mathrm{s})$

\subsection{Head Losses}

Head losses adalah head atau kerugian-kerugian dalam aliran pipa yang terdiri atas mayor losses dan minor losses. (Sularso, 2000).

$$
\mathrm{H}=\mathrm{H}_{\mathrm{f}}+\mathrm{H}_{\mathrm{m}}
$$

Dimana:

$\mathrm{H}=$ head losses $(\mathrm{m})$

$\mathrm{H}_{\mathrm{f}}=$ mayor losses $(\mathrm{m})$

$\mathrm{H}_{\mathrm{m}}=$ minor losses $(\mathrm{m})$

\subsubsection{Mayor Losses}

Kerugian mayor adalah kehilangan tekanan akibat gesekan aliran fluida pada sistem aliran dengan luas penampang tetap atau konstan. Aliran fluida yang melalui pipa akan selalu mengalami kerugian head. Hal ini disebabkan oleh gesekan yang terjadi antara fluida dengan dinding pipa atau perubahan kecepatan yang dialami oleh fluida.

Kerugian head akibat dari gesekan dapat dihitung dengan menggunakan Persamaan Darcy - Weisbach yaitu:

$$
\mathrm{H}_{\mathrm{f}}=\mathrm{f} \cdot \frac{\mathrm{L}}{\mathrm{D}} \cdot \frac{\mathrm{v}^{2}}{2 \mathrm{~g}}
$$

Dimana:

$\mathrm{H}_{\mathrm{f}}=$ head mayor $(\mathrm{m})$

$\mathrm{L}=$ panjang pipa $(\mathrm{m})$

$\mathrm{D}=$ diameter pipa $(\mathrm{m})$

$\mathrm{v}=$ kecepatan $(\mathrm{m} / \mathrm{s})$

$\mathrm{g}=$ gravitasi bumi $\left(\mathrm{m} / \mathrm{s}^{2}\right)$

$\mathrm{f}=$ factor gesek (didapat dari diagram mody)

Diagram mody telah digunakan untuk menyelesaikan permasalahan aliran fluida dalam pipa dengan menggunakan faktor gesekan pipa (f) dari rumus Darcy Weisbach. Untuk aliran laminar dimana bilangan Reynold kurang dari 2300 $(\operatorname{Re}<2300)$, factor gesekan pada persamaan 2.6 dihubungkan dengan bilangan Reynold, dengan rumus:

$$
\mathrm{f}=\frac{64}{\mathrm{Re}}
$$

Untuk aliran turbulen dimana bilangan Reynold lebih besar dari 4000 (Re>4000), maka fungsional dari factor gesekan (f) pada persamaan 2.6 tergantung pada bilangan Reynold dan kekasaran relatif, $f=\varnothing \dot{\varnothing}(\operatorname{Re}, \varepsilon / D)$. nilai $\varepsilon$ untuk pipa PVC adalah 0.0015-0.007 $\mathrm{mm}$ (engineering.toolbox.com)

\subsubsection{Minor Losses}

Kerugian minor adalah kehilangan tekanan akibat gesekan yang terjadi pada katup-katup, sambungan Tee, sambungan belokan, dan pada luas penampang yang tidak konstan. Pada aliran yang melewati belokan dan katup head loss minor yang terjadi dapat dihitung dengan rumusan Darcy - Weisbach (White, 1988) yaitu:

$$
\mathrm{H}_{\mathrm{m}}=\mathrm{k} \frac{\mathrm{v}^{2}}{2 \mathrm{~g}}
$$

Dimana :

$\mathrm{H}_{\mathrm{m}}=$ head minor $(\mathrm{m})$

$\mathrm{v}=\operatorname{kecepatan}(\mathrm{m} / \mathrm{s})$

$\mathrm{g}=$ gravitasi bumi $\left(\mathrm{m} / \mathrm{s}^{2}\right)$

$\mathrm{k}=$ koefisien kerugian pada fiting

\subsubsection{Koefisien kerugian pada belokan pipa \\ Ada dua macam belokan pipa yaitu} belokan lengkung dan belokan patah. Untuk belokan lengkung sering dipakai rumus Fuller dimana k pada persamaan 2.8 dinyatakan sebagai berikut (Sularso, Haruo Tahara: 2000).

$$
\mathrm{k}=\left[0,131+1,847\left(\frac{\mathrm{D}_{\mathrm{b}}}{2 \mathrm{R}}\right)^{3,5}\right]\left[\frac{\theta}{90}\right]^{0,5}
$$

Dimana :

$D_{b}=$ Diameter dalam belokan $(m)$

$\mathrm{R}=$ Jari-jari lengkung sumbu belokan $(\mathrm{m})$

$\theta=$ sudut belokan (derajat)

$\mathrm{k}=$ koefisien kerugian

Hubungan di atas di lihatkan dalam gambar 2.

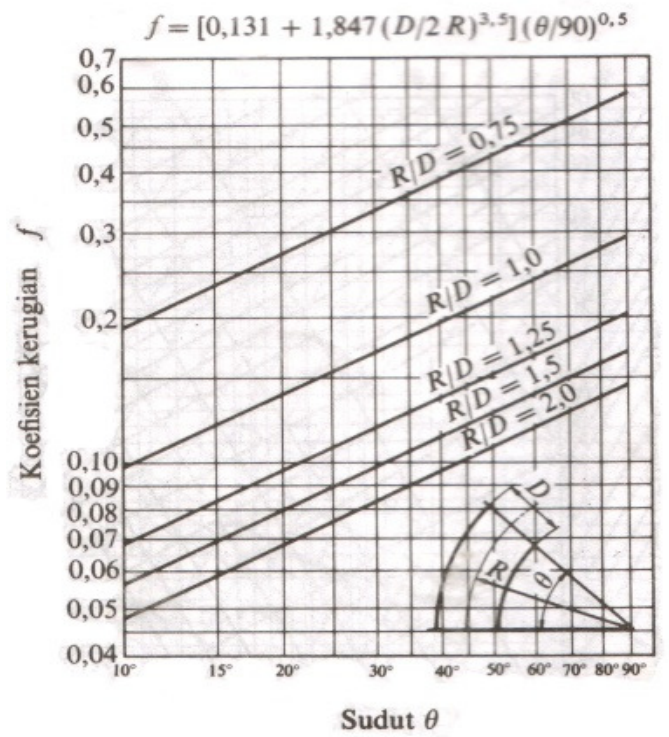

Gambar 2. koefisien kerugian pada belokan (Sularso, Haruo Tahara, 2000)

Dari percobaan Weisbach dihasilkan rumus yang umum dipakai untuk belokan patah sebagai berikut (Sularso, Haruo Tahara: 2000). 


$$
\mathrm{k}=0,946 \sin ^{2} \frac{\theta}{2}+2,047 \sin ^{4} \frac{\theta}{2}
$$

Dimana:

$\theta=$ sudut belokan (derajat)

$\mathrm{k}=$ koefisien kerugian

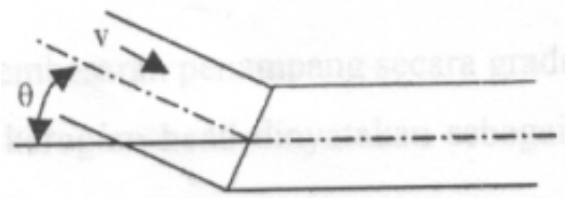

Gambar 3. Bentuk belokan patah pipa (Sularso, Haruo Tahara: 2000)

\subsection{Pressure Drop}

Pressure drop adalah istilah yang digunakan untuk menggambarkan penurunan tekanan dari satu titik di dalam pipa atau aliaran air. "Penurunan Tekanan" adalah hasil dari gaya gesek pada fluida seperti yang mengalir melalui tabung. Gaya gesek disebabkan oleh resistensi terhadap aliran. Faktor utama yang mempengaruhi resistensi terhadap aliran fluida adalah kecepatan fluida melalui pipa dan viskositas fluida. Aliran cairan atau gas selalu akan mengalir ke arah perlawanan sedikit (kurang tekanan). Pada aliran satu fase, pressure drop dipengaruhi oleh Reynold number yang merupakan fungsi dari viskositas, densitas fluida dan diameter pipa.

Secara matematis pressure drop pada pipa horizontal adalah sebagai berikut:

$$
\Delta \mathrm{p}=\text { o.g. } \Delta \mathrm{h}
$$

Dimana:

$\Delta \mathrm{p}=$ pressure drop $\left(\mathrm{N} / \mathrm{m}^{2}\right)$

$\rho=$ massa jenis fluida $\left(\mathrm{kg} / \mathrm{m}^{3}\right)$

$\mathrm{g}=$ gravitasi $\left(\mathrm{m} / \mathrm{s}^{2}\right)$

$\Delta \mathrm{h}=$ selisih ketinggian pada manometer $(\mathrm{m})$

\subsection{Manometer}

Manometer adalah suatu alat pengukur tekanan yang menggunakan kolom cairan untuk mengukur perbedaan tekanan antara suatu titik tertentu dengan tekanan atmosfer (tekanan terukur), atau perbedaan tekanan antara dua titik. Manometer yang paling sederhana adalah piezometer, kemudian manometer pipa $U$, dan yang lebih rumit adalah manometer deferensial.

\subsubsection{Piezometer}

Alat ini tidak dapat digunakan untuk mengukur tekanan negatif, oleh karena itu dikembangkan monometer dengan menggunakan pipa $U$ agar tekanan positif atau negatif dapat terukur.

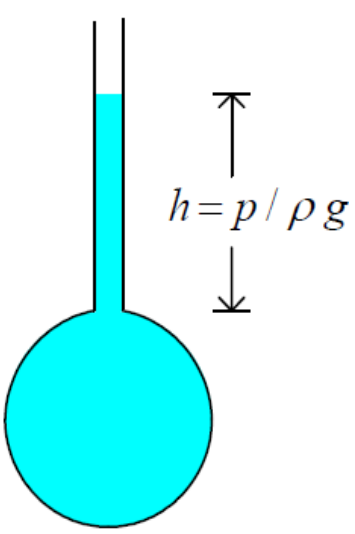

Gambar 4. Piezometer

(Bruce R. Munson, 2003)

\subsubsection{Manometer Pipa U biasa}

Manometer ini tidak banyak bedanya dengan tabung piezometer, hanya saja manometer ini berbentuk pipa $U$ ( $U$ tube) dimana ujung yang satu melekat pada titik yang diukur tekanannya sedang ujung yang lain berhubungan langsung dengan udara luar (atmosfer).

Pipa $U$ tersebut diisi dengan cairan yang berbeda dengan cairan yang mengalir di dalam pipa yang akan diukur tekanannya. Misalnya berat jenis cairan di dalam pipa adalah $\mathrm{y} 1$ dan berat jenis cairan di dalam manometer adalah $\mathrm{y} 2$ dimana $\mathrm{\gamma} 2>\mathrm{\gamma} 1$.

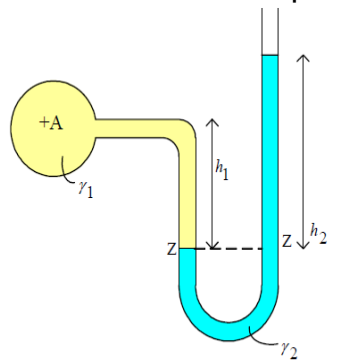

(a) Tekanan positip

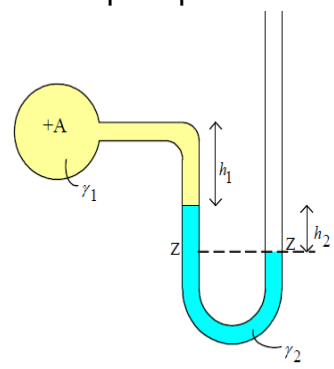

(b) Tekanan negatip
Gambar 5. Manometer Pipa U

(Bruce R. Munson, 2003)

$$
\mathrm{p}_{\mathrm{A}}=\mathrm{p}_{\mathrm{atm}}+\mathrm{h}_{2} \mathrm{Y}_{2}-\mathrm{h}_{1} \mathrm{Y}_{1}
$$

Dimana:

$\mathrm{p}_{\mathrm{A}}=$ tekanan $\operatorname{di}$ titik $\mathrm{A}\left(\mathrm{N} / \mathrm{m}^{2}\right)$

$\mathrm{p}_{\mathrm{atm}}=$ tekanan atmosfer $\left(\mathrm{N} / \mathrm{m}^{2}\right)$

$\mathrm{h}_{1}=$ beda tinggi fluida 1 dan $2(\mathrm{~m})$

$\mathrm{h}_{2}=$ beda tinggi fluida 2 dan atmosfer $(\mathrm{m})$

$\mathrm{V}_{1,2}=$ berat jenis fluida 1 dan $2\left(\mathrm{~N} / \mathrm{m}^{3}\right)$

\subsubsection{Manometer PipaU Diferensial} Manometer U Deferensial digunakan untuk mengukur tekanan antara dua tempat pada satu pipa atau antara dua pipa. Manometer diferensial terdiri dari pipa $U$ 
dimana kedua ujungnya terletak pada tempat yang diukur, seperti pada Gb.6.

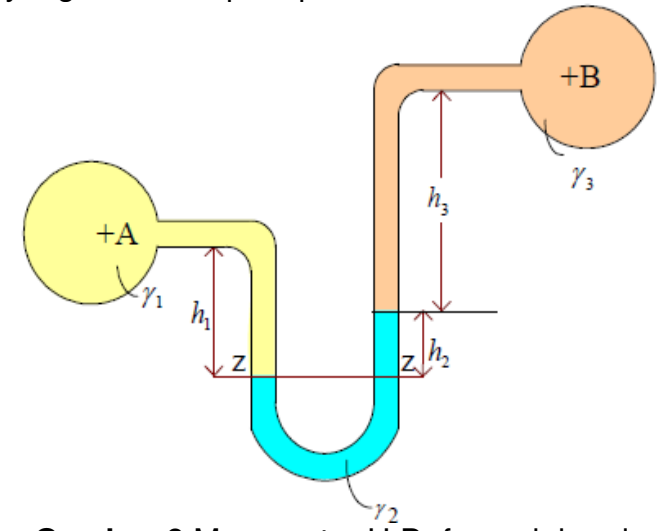

Gambar 6 Manometer U Deferensial pada dua pipa (Bruce R. Munson, 2003)

Dengan mengikuti prosedur yang diuraikan untuk monometer sederhana persamaan untuk perbedaan tekanan antara pipa $A$ dan pipa $B$ adalah:

$$
\mathrm{p}_{\mathrm{A}}-\mathrm{P}_{\mathrm{B}}=\mathrm{h}_{2} \mathrm{Y}_{2}+\mathrm{h}_{3} \mathrm{~V}_{3}-\mathrm{h}_{1} \mathrm{Y}_{1}
$$

Manometer deferensial tersebut juga dapat dipasang diatara dua penampang pada satu aliran saluran tertutup seperti tampak pada Gambar. 7.

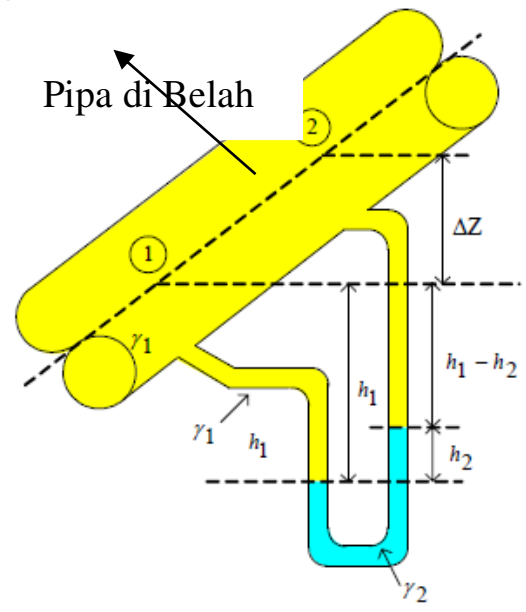

Gambar 7. Manometer U Diferensial pada satu pipa (Bruce R. Munson, 2003)

$\mathrm{p}_{1}-\mathrm{p}_{2}=\mathrm{h}_{2} \mathrm{Y}_{2}-\mathrm{Y}_{1}\left(\mathrm{~h}_{2}-\Delta \mathrm{z}\right)$

Dengan:

$$
\begin{aligned}
& \mathrm{p}_{1}-\mathrm{p}_{2}= \text { beda tekanan (pressure drop) } \\
& \quad\left(\mathrm{N} / \mathrm{m}^{2}\right) \\
& \Delta \mathrm{z}= \text { perbedaan ketinggian antara titik } 1 \\
& \text { dan } 2(\mathrm{~m}) \\
& \mathrm{h}_{2}= \text { beda tinggi tekan }(\mathrm{m}) \\
& \mathrm{V}_{1}= \text { berat jenis fluida } 1\left(\mathrm{~N} / \mathrm{m}^{3}\right) \\
& \mathrm{V}_{2}= \text { berat jenis fluida } 2\left(\mathrm{~N} / \mathrm{m}^{3}\right)
\end{aligned}
$$

\section{Metode Penelitian}

prosedur penelitian yang akan dilakukan oleh penulis dalam rangka mengumpulkan data hingga penyelesaian masalah dalam penelitian ini adalah sebagai berikut :

1. Menyiapkan alat dan bahan

2. Merencanakan instalasi pengujian

3. Menyiapkan minimal delapan sambungan belokan $45^{\circ}$.

4. Memotong dua belokan $45^{\circ}$ dengan sudut masing-masing $15^{\circ}$ yang digunakan untuk membuat belokan $30^{\circ}$.

5. Memotong dua belokan $45^{\circ}$ dengan sudut masing-masing $22,5^{\circ}$ yang digunakan untuk membuat belokan $45^{\circ}$.

6. Memotong dua belokan $45^{\circ}$ dengan sudut masing-masing $30^{\circ}$ yang digunakan untuk membuat belokan $60^{\circ}$.

7. Memotong dua belokan $45^{\circ}$ dengan sudut masing-masing $45^{\circ}$ yang digunakan untuk membuat belokan $90^{\circ}$.

8. Menyambung semua sudut yang telah dipotong menggunakan resin dan serat.

9. Memasang instalasi pipa (PVC) sesuai dengan yang direncanakan (gambar 8)

10. Menghubungkan instalasi pipa dengan pompa dan sumber air

11. Memasang manometer diferensial sebelum dan setelah sambungan belokan.

12. Sebelum pengambilan data instalasi dioperasikan kurang lebih satu menit, hal ini dimaksudkan agar gelembunggelembung udara yang terjebak disepanjang saluran dapat dihilangkan dan alirannya stabil.

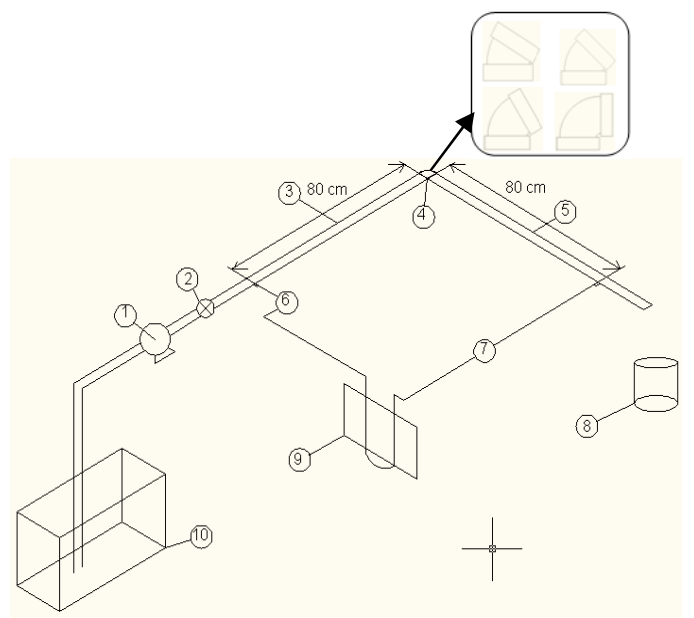

Gambar 8. Rangkaian alat uji

13. Mengukur debit menggunakan tabung ukur dalam meter kubik per satuan waktu. Untuk mengukur debit ini, 
volume air yang akan mengisi tabung ukur ditentukan terlebih dahulu, selanjutnya mencatat waktu lama air memenuhi volume tersebut.

14. Mencatat perbedaan tekanan sebelum dan setelah sambungan belokan yang terbaca pada manometer.

15. Mencatat ulang debit dan perbedaan tekanan setiap perubahan sudut sambungan belokan.

\section{Hasil dan Pembahasan}

\subsection{Data Hasil Perhitungan}

Berikut adalah data hasil perhitungan debit, kecepatan, bilangan Reynold, mayor losses, minor losses, head losses, dan pressure drop untuk setiap sudut sambungan belokan yang disajikan dalam bentuk tabel.

Tabel 1 Data hasil perhitungan debit, kecepatan, dan bilangan Reynold

\begin{tabular}{cccc}
\hline Belokan & $\begin{array}{c}\text { Debit } \\
(\mathbf{Q}) \\
(\mathbf{l i t r} / \mathbf{s})\end{array}$ & $\begin{array}{c}\text { Kecepatan } \\
(\mathbf{v})(\mathbf{m m} / \mathbf{s})\end{array}$ & $\begin{array}{c}\text { Bilangan } \\
\text { Reynold } \\
(\mathbf{R e})\end{array}$ \\
\hline $30^{\circ}$ & 1,2068 & 1064,597 & 46128,48 \\
\hline $45^{\circ}$ & 1,1701 & 1033,424 & 44777,78 \\
\hline $60^{\circ}$ & 1,1421 & 1007,537 & 43656,09 \\
\hline $90^{\circ}$ & 1,1034 & 973,377 & 42175,96 \\
\hline
\end{tabular}

Tabel 2 Data hasil perhitungan mayor losses, minor losses, head losses, dan pressure drop

\begin{tabular}{ccccc}
\hline $\begin{array}{c}\text { Belo } \\
\text { kan }\end{array}$ & $\begin{array}{c}\text { Mayor } \\
\text { Losses } \\
\left(\mathbf{H}_{\mathbf{f}}\right) \\
(\mathbf{m m})\end{array}$ & $\begin{array}{c}\text { Minor } \\
\text { Losses } \\
\left(\mathbf{H}_{\mathbf{m}}\right) \\
(\mathbf{m m})\end{array}$ & $\begin{array}{c}\text { Head } \\
\text { Losses } \\
\mathbf{( H )} \\
(\mathbf{m m})\end{array}$ & $\begin{array}{c}\text { Pressure } \\
\text { Drop } \\
(\mathbf{\Delta} \mathbf{p}) \\
\left(\mathbf{N} / \mathbf{m}^{2}\right)\end{array}$ \\
\hline $30^{\circ}$ & 51,03 & 22,20 & 73,23 & 907,606 \\
\hline $45^{\circ}$ & 48,08 & 25,66 & 73,74 & 1072,625 \\
\hline $60^{\circ}$ & 45,71 & 28,17 & 73,88 & 1113,880 \\
\hline $90^{\circ}$ & 42,66 & 32,15 & 74,80 & 1278,899 \\
\hline
\end{tabular}

\subsection{Pembahasan}

4.1.1 Hubungan Antara Sudut Belokan Dengan Debit Air

Berikut adalah grafik hasil pengujian debit air dengan variasi sudut sambungan belokan. Pengambilan data dilakukan sebanyak tiga kali dan diambil nilai rataratanya. Hal ini ditujukan agar diperoleh sebuah data tentang debit aktual dengan variasi sudut sambungan belokan.

Pada gambar 9 menunjukkan sudut belokan $30^{\circ}$ memiliki debit rata-rata yang paling besar yaitu 1,207 liter/s, sedangkan pada sudut belokan $45^{\circ}$ dan $60^{\circ}$ memiliki debit rata-rata yaitu 1,170 liter/s dan 1,142 liter/s, dan sudut belokan $90^{\circ}$ memiliki debit terkecil yaitu 1,103 liter/s.
Hasil pengujian pada diameter yang sama dan panjang pipa yang sama menunjukkan bahwa debit air berbanding terbalik dengan sudut sambungan belokan pipa, semakin besar sudut sambungan belokan pipa maka debit air semakin kecil, dan sebaliknya semakin kecil sudut sambungan belokan pipa debit air semakin besar. Hal tersebut disebabkan karenan waktu yang diperlukan lebih lama untuk sudut belokan yang semakin besar.

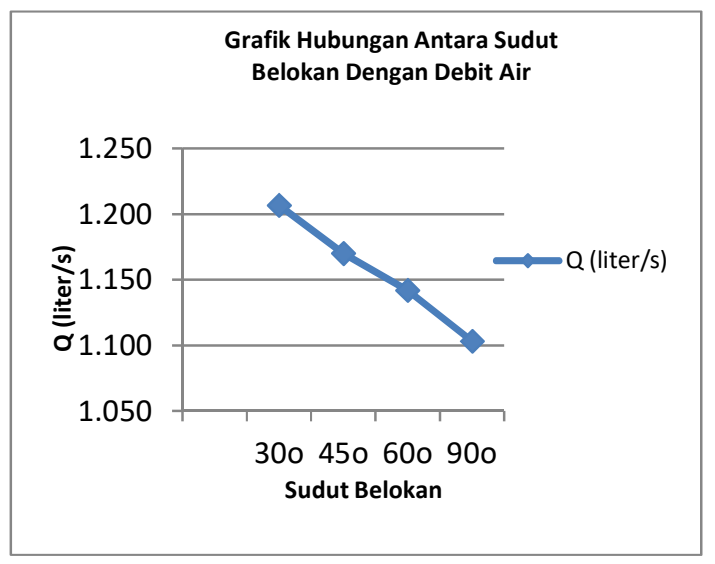

Gambar 9 Grafik hubungan antara sudut belokan dengan debit air

\subsubsection{Hubungan Antara Sudut Belokan Dengan Kecepatan Air}

Berikut adalah grafik hasil pengujian kecepatan aktual pada pengujian kecepatan air dengan variasi sudut sambungan belokan.

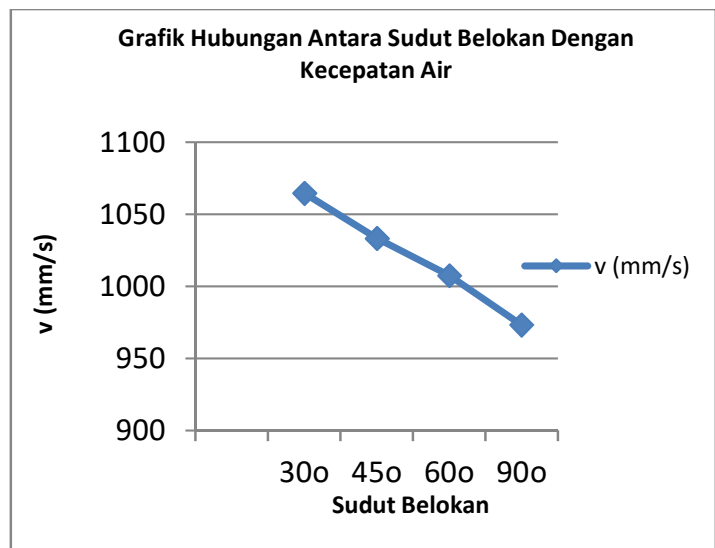

Gambar 10 Grafik hubungan antara sudut belokan dengan kecepatan air

Pada variasi sudut sambungan belokan pipa, sudut belokan $30^{\circ}$ memiliki kecepatan air rata-rata terbesar yaitu 1064,6 $\mathrm{mm} / \mathrm{s}$, sedangkan pada sudut belokan $45^{\circ}$ dan $60^{\circ}$ memiliki kecepatan air rata-rata 
sebesar 1033,42 mm/s dan 1007,54 mm/s, dan sudut belokan $90^{\circ}$ memiliki kecepatan terkecil yaitu $973,38 \mathrm{~mm} / \mathrm{s}$.

Hasil pengujian menunjukkan bahwa kecepatan air berbanding terbalik dengan sudut sambungan belokan pipa, semakin besar sudut sambungan belokan pipa maka kecepatan air semakin kecil, dan sebaliknya semakin kecil sudut sambungan belokan pipa kecepatan air semakin besar. Hal tersebut disebabkan karenan waktu yang diperlukan lebih lama untuk sudut belokan yang semakin besar.

\subsubsection{Hubungan Antara Sudut Belokan Dengan Mayor Losses dan Minor Losses}

Berikut adalah grafik hasil pengujian mayor losses dan minor losses.

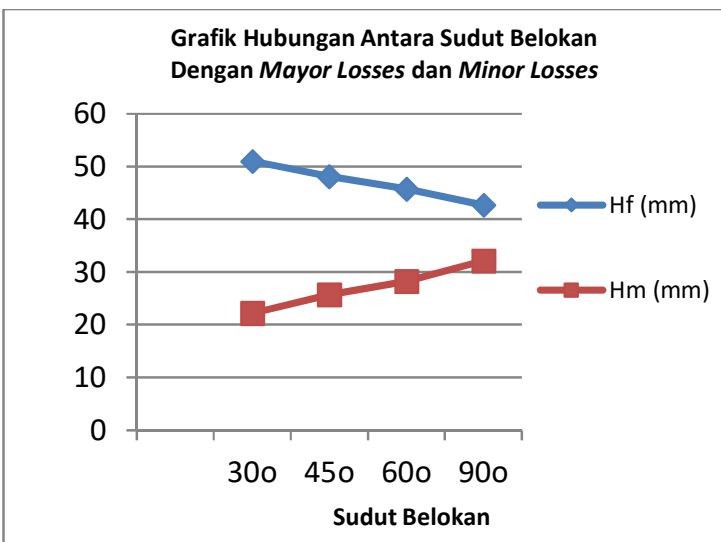

Gambar 11 Grafik hubungan antara sudut belokan dengan mayor losses dan minor losses

Pada variasi sudut sambungan belokan, mayor loses paling besar ditunjukan oleh sambungan belokan $30^{\circ}$ yaitu $51,03 \mathrm{~mm}$ dan mayor losses paling kecil ditunjukkan oleh sudut belokan $90^{\circ}$ yaitu $42,66 \mathrm{~mm}$, sedangkan pada minor losses nilai terbesar ditunjukkan oleh sudut belokan $90^{\circ}$ yaitu $32,15 \mathrm{~mm}$ ' dan minor losses paling kecil ditunjukkan oleh sudut belokan $30^{\circ}$ yaitu $22,20 \mathrm{~mm}$

Hasil pengujian pada diameter yang sama dan panjang pipa yang sama menunjukkan bahwa mayor losses berbanding terbalik dengan sudut sambungan belokan pipa, sedangkan minor losses berbanding lurus dengan sambungan belokan pipa. Pada pengujian tersebut, semakin besar sudut sambungan belokan pipa mayor losses yang dihasilkan semakin kecil, sedangkan minor losses yang dihasilkan semakin besar seiring dengan naiknya sudut sambungan belokan pipa.

\subsubsection{Hubungan Antara Sudut Belokan Dengan Head Losses \\ Berikut adalah grafik hasil pengujian} head losses dengan variasi sudut sambungan belokan.

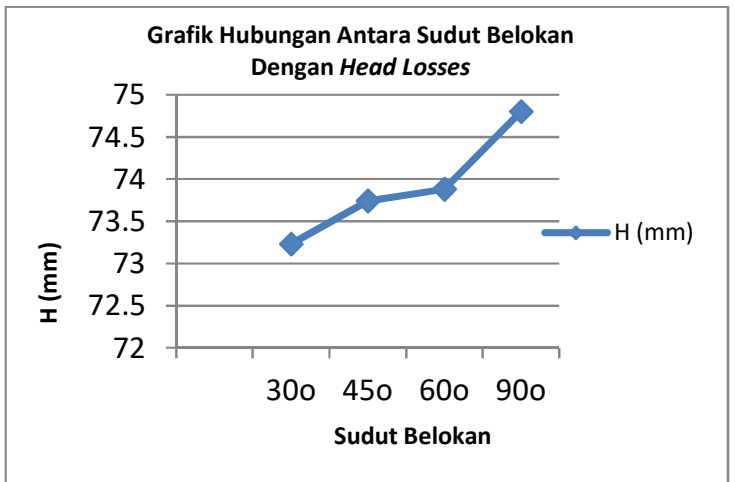

Gambar 12 Grafik hubungan antara sudut belokan dengan head losses

Pada gambar 12 hasil pengujian head losses terbesar ditunjukkan oleh sudut sambungan belokan $90^{\circ}$ yaitu $74,8 \mathrm{~mm}$, sedangkan sudut belokan $45^{\circ}$ dan $60^{\circ}$ nilai head losses adalah 73,74 mm dan 73,88 mm, dan nilai head losses terkecil ditunjukkan oleh sudut belokan $30^{\circ}$ yaitu $73,23 \mathrm{~mm}$.

Hasil pengujian head losses menunjukkan bahwa, sudut sambungan belokan berbanding lurus dengan head losses. Semakin besar sudut sambungan belokan pipa, nilai head losses semakin besar. Hal ini disebabkan karena peningkatan nilai minor losses lebih besar dari penurunan nilai mayor losses.

\subsubsection{Hubungan Antara Sudut Belokan Dengan Pressure Drop \\ Berikut adalah grafik hasil pengujian} pressure drop dengan variasi sudut sambungan belokan.

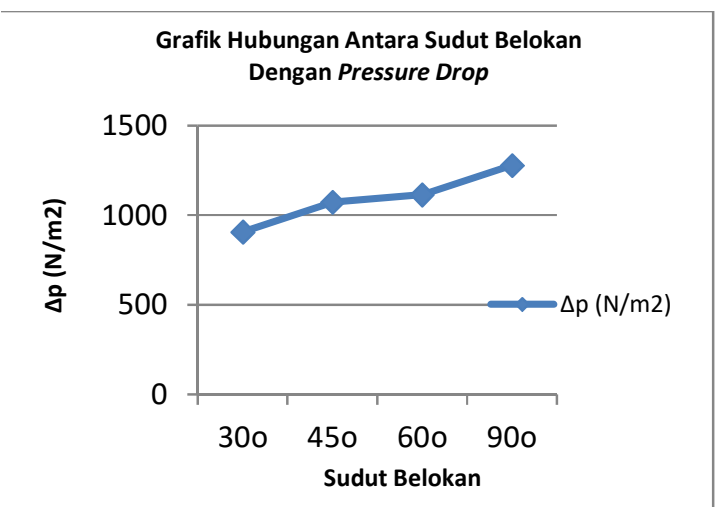

Gambar 13 Grafik hubungan antara sudut belokan dengan pressure drop 
Grafik hubungan antara sudut sambungan belokan dengan pressure drop menunjukkan bahwa, nilai pressure drop terbesar ditunjukkan oleh sudut sambungan belokan $90^{\circ}$ yaitu $1278.899 \mathrm{~N} / \mathrm{m}^{2}$, sedangkan nilai pressure drop pada sudut belokan $45^{\circ}$, dan $60^{\circ}$ sebesar $1072.625 \quad \mathrm{~N} / \mathrm{m}^{2}$ dan $1113.880 \mathrm{~N} / \mathrm{m}^{2}$, dan nilai pressure drop terkecil ditunjukkan oleh sudut $30^{\circ}$ yaitu $907.606 \mathrm{~N} / \mathrm{m}^{2}$.

Hasil pengujian pressure drop menunjukkan bahwa, sudut sambungan belokkan berbanding lurus dengan pressure drop. Semakinn besar sudut sambungan belokan pipa, nilai pressure drop yang dihasilkan semakin besar. Hal ini disebabkan oleh perbedaan tinggi tekan pada sebelum dan setelah belokan pipa yang semakin meningkat.

\subsubsection{Hubungan Pressure Drop Dengan Bilangan Reynold}

Berikut adalah grafik hasil pengujian perbandingan antara bilangan Reynold dan pressure drop dengan variasi sudut sambungan belokan.

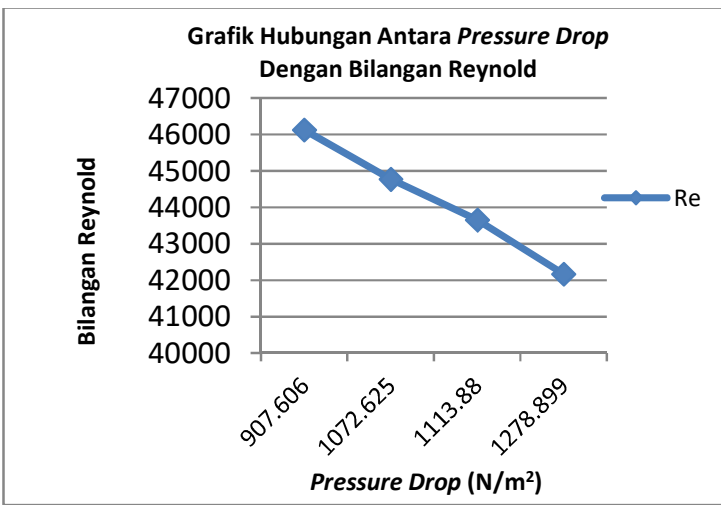

Gambar 13 Grafik hubungan antara pressure drop dan bilangan Reynold

Pada gambar 13 di atas, pada sudut yang sama yaitu sudut $30^{\circ}$ pressure drop memiliki nilai paling kecil yaitu 907,606 N/m², sedangkan bilangan Reynold memiliki nilai paling tinggi yaitu 46128,48 . Dan pada sudut $90^{\circ}$ pressure drop memiliki nilai paling besar yaitu $1278.899 \mathrm{~N} / \mathrm{m}^{2}$, sedangkan bilangan Reynold memiliki nilai paling kecil yaitu 42175.96.

Hasil pengujian menunjukkan bahwa, pada variasi sudut sambungan belokan pipa mengakibatkan pressure drop berbanding terbalik dengan bilangan Reynold. semakin besar nilai pressure drop maka bilangan Reinold semakin kecil. Naiknya nilai pressure drop disebabkan oleh semakin besarnya sudut sambungan belokan pipa sehingga mengakibatkan perbedaan tinggi tekanan meningkat, sedangkan mengecilnya bilangan Reinold disebabkan oleh semakin besarnya sudut sambungan belokan pipa sehingga mengakibatkan kecepatan air dalam pipa semakin menurun.

\subsubsection{Hubungan Head Losses dan Kecepatan \\ Berikut adalah grafik hasil pengujian} perbandingan antara head losses dan kecepatan dengan variasi sudut sambungan belokan.

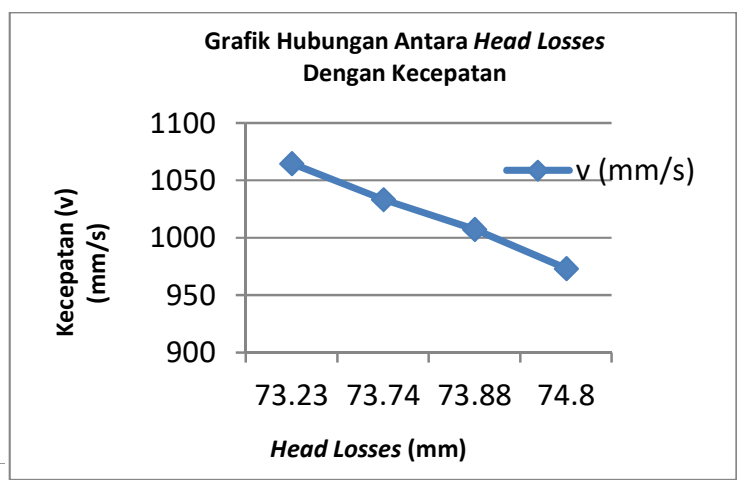

Gambar 14 Grafik hubungan antara head losses dan kecepatan

Pada gambar 14 menunjukkan bahwa, pada sudut yang sama yaitu sudut belokan $30^{\circ}$ head losses memiliki nilai paling kecil yaitu $73,23 \mathrm{~mm}$, sedangkan kecepatan memiliki nilai paling tinggi yaitu 1064,597 $\mathrm{mm} / \mathrm{s}$. Dan pada sudut belokan $90^{\circ}$ head losses memiliki nilai paling besar yaitu 74,80 $\mathrm{mm}$, sedangkan kecepatan memiliki nilai paling kecil yaitu $973,377 \mathrm{~mm} / \mathrm{s}$.

Hasil pengujian menunjukkan bahwa, pada variasi sudut sambungan belokan pipa mengakibatkan head losses berbanding terbalik dengan kecepatan. semakin besar nilai head losses maka kecepatan semakin kecil. Naiknya nilai head losses disebabkan oleh semakin besarnya sudut sambungan belokan pipa sehingga mengakibatkan nilai minor losses semakin besar walaupun terjadi penurunan pada mayor losses, sedangkan mengecilnya kecepatan disebabkan oleh semakin besarnya sudut sambungan belokan pipa sehingga mengakibatkan waktunya semakin bertambah.

\section{Penutup \\ 5.1 Kesimpulan}

Dari hasil penelitian yang telah dilakukan dapat diambil beberapa kesimpulan sebagai berikut: 
1. Pemakaian variasi sudut belokan menyebabkan perubahan pada head losses dan pressure drop. Semakin besar sudut belokan, nilai head losses dan pressure drop yang dihasilkan semakin besar. Head losses dan pressure drop paling kecil terjadi pada sudut $30^{\circ}$ yaitu $73,23 \mathrm{~mm}$ dan $907,606 \mathrm{~N} / \mathrm{m}^{2}$, sedangkan head losses dan pressure drop paling besar terjadi pada sudut $90^{\circ}$ yaitu 74,80 $\mathrm{mm}$ dan $1278,899 \mathrm{n} / \mathrm{m}^{2}$.

2. Berdasarkan perhitungan data hasil pengujian yang telah dilakukan, pemakaian sudut belokan yang semakin besar menyebabkan hubungan kecepatan air berbanding terbalik dengan head losses. Semakin kecil kecepatan yang dihasilkan, nilai head losses semakin besar.

\subsection{Saran}

Adapun saran yang diberikan dalam penelitian ini adalah:

1. Hendaknya alat penelitian lebih disempurnakan lagi untuk mendapatkan ketepatan pengukuran, terutama pada pemasangan manometer perlu ketelitian.

2. Hendaknya penelitian ini dikembangkan lebih lanjut, misalnya dengan fluida yang berbeda dan dengan variasi material penyusun pipa yang digunakan.

\section{Daftar Pustaka}

Efriandi, Rohman. 2004. Pengaruh Jumlah Saluran Distribusi Terhadap Total Kerugian Head Pada Instalasi Pompa Sentrifugal. Unram, Mataram

Haruo Tahara, Sularso, 2000. Pompa dan Kompresor. Penerbit PT. Pradnya Pramita, Jakarta.

Jack B. event. 1987. Fundamentals of Fluids Mechanics. McGraw Hill. New York

M. White, Frank dan Hariandja, Manahan. 1988. Mekanika Fluida (terjemahan). Erlangga, Jakarta.

Mody, L. F., Friction Factors for Pipe Flow. Transaction of the ASME, vol. 66, 1944

Muttaqin, Muhammad. 2004. Analisa Kinerja Instalasi Pompa Sentrifugal Untuk Memenuhi Kebutuhan Air di Pdam Praya Lombok Tengah. Unram, mataram.

Raswari. 1986. Teknologi dan Perencanaan Sistem Perpipaan. Penerbit Universitas Indonesia, Jakarta.

Streeter, Victor L. dan Prijono, Arko 1988. Mekanika Fluida (terjemahan). Erlangga, Jakarta.

Suhariono, Edi. 2008. Analisa Head Losses dan Koefisien Gesek Pada Pipa. Kalimantan Scientiae.

www.engineering.toolbox.com 